ECOLOGICA, Vol. 28, No 104 (2021), 551-556

https://doi.org/10.18485/ecologica.2021.28.104.9

Originalni naučni rad

UDC: $338.48-6: 502 / 504]:[616.98: 578.834](497.113)$

\title{
Razvoj ekoturizma u vreme pandemije COVID-19, studija slučaja Palićko jezero
}

\section{Development of ecotourism during the COVID-19 pandemic, case study Palić Lake}

\author{
Doc. Bojana Ostojićn ${ }^{*}$, Doc. Miodrag Bogdanović ${ }^{2}$ Doc. Miodrag Vuković3 \\ 1,2,3Fakultet za projektni i inovacioni menadzment PMC, Beograd, Srbija / \\ Faculty of Project and Innovation Management PMC, Belgrade, Serbia \\ *Autor za prepisku / Corresponding author
}

Rad primljen / Received: 12.09.2021, Rad prihvaćen / Accepted: 07.11.2021.

\begin{abstract}
Sažetak: U skorijoj prošlosti bilo je mnogo inicijativa koje sprečavaju negativne posledice turizma na životnu sredinu. Masovnost, koja je osnovna karakteristika turizma, neminovno ima izvestan uticaj na ekonomske, društvenokulturne i prirodne resurse. $U$ tom smislu, došlo je do pojave ekoturizma, selektivnog oblika turizma zasnovanog na prirodnim vrednostima, usmerenog na iskustvo učenja, ekološki i socio-kulturni održivi razvoj. Osnovna ideja održivog razvoja turizma je da se pravilno pokrene razvoj privrede koja nije štetna po životnu sredinu i društveno prihvatljiva. Danas, obeleženo pandemijom virusa COVID-19, turizam se generalno suočava sa brojnim izazovima, a jedan od njih je razvoj ekoturizma. Naime, ono što karakteriše turizam u prethodnoj godini jeste činjenica da je značajno povećan broj domaćih turista na lokalitetima širom Republike Srbije, jer su putovanja u druge zemlje značajno ograničena. Nagli porast turista dovodi do urušavanja pojedinih resursa, što ne ispunjava osnovne postulate ekoturizma. Cilj ovog rada je da na primeru dobre prakse pokaže kako je moguće razvijati ekoturizam u eri pandemije COVID-19. Studija slučaja Palićkog jezera pružiće uvid u moguća rešenja ovog problema.
\end{abstract}

Ključne reči: ekoturizam, pandemija, COVID-19, jezero Palić.

\begin{abstract}
In the recent past, there have been many initiatives that prevent the negative consequences of tourism on the environment. Mass, which is the basic characteristic of tourism, inevitably has a certain impact on economic, socio-cultural and natural resources. In this sense, there has been the emergence of ecotourism, a selective form of tourism based on natural values, focused on the learning experience, ecological and socio-cultural sustainable development. The basic idea of sustainable tourism development is to properly start the development of an economy that is not harmful to the environment and is socially acceptable. Nowadays, marked by the COVID-19 virus pandemic, tourism generally faces many challenges, and one of them is the development of ecotourism. Namely, what characterizes tourism in the previous year is the fact that the number of domestic tourists has significantly increased in localities throughout the Republic of Serbia, since travel to other countries is significantly limited. The sudden increase of tourists leads to the devastation of certain resources, which does not fulfill the basic postulates of ecotourism. The aim of this paper is to show how it is possible to develop ecotourism in the era of the COVID-19 pandemic through the example of good practice. The case study of Lake Palić will provide an insight into possible solutions to this problem.
\end{abstract}

Keywords: ecotourism, pandemic, COVID-19, Lake Palić.

\footnotetext{
1orcid.org/0000-0001-6731-431X, e-mail: bojanaostojic2002@yahoo.com

2orcid.org/0000-0002-0342-7443, e-mail:miodrag.bogdanovic@pmc.edu.rs

3orcid.org/0000-0003-0158-192X, e-mail:miodrag.vukovic@pmc.edu.rs
} 


\section{UVOD / INTRODUCTION}

Internacionalna delovanja istraživača, koji se bave novonastalom pandemijom KOVID-19, imaju za cilj da zaštite ljudsku populaciju i privredne grane koje su najviše stagnirale njegovom pojavom i ponude im određena rešenja. Među tim privrednim granama nalazi se i turizam, kao posebno ugrožen deo privrede koji svim zemljama donosi velike prihode. On, u vreme pandemije, proživljava svoje gubitke, usled straha i skepticizma koji se javlja kod ljudi u vezi sa putovanjima i obilascima poznatih, mnogoljudnih evropskih i svetskih destinacija. Da bi turizam, u ovom trenutku, održao svoj sektor, neophodno je da razvije posebnu strategiju koja je okrenuta ka ekoturizmu kojim se promovišu sledećih pet ključnih aspekata:

- da se kod turističkih posetilaca razvije otvorenost za promene, što podrazumeva novi način razmišljanja i delovanja.

- da se razviju određene vizije koje obuhvataju načine na koje treba probuditi zainteresovanost turističkih posetilaca ka novim ekološkim destinacijama i ekoturizmu.

- da se zašti prirodno i kulturno nasleđe, zbog njegovog značaja za usluge i zaštitu životne sredine turističkih područja.

- da se radi na oporavku i obnovi lokalnih sredstava za život i zdravlju stanovnika i turističkih posetilaca.

- da se modifikuje turizam, uključujući resurse koje koristi za postizanje produktivnih i zdravih sredstava za život, bez pogoršanja biodiverziteta od koga zavisi.

Potreba ljudi, pod pritiskom nastalim usled dejstva KOVID-19 virusa je takva da oni svoj komoditet pronalaze u prirodnim, ruralnim područjima. "Savremeni svet promenio je navike ljudi" (Živadinović, 2020), jer, već je dokazano da se kod ljudi "ekološka svijest počela razvijati uporedo sa nastankom prvih ekoloških problema koji su nastajali i umnožavali se uporedo sa ekonomskim i tehnološkim napretkom" (Bulatović i dr., 2019). Možda bi se, u ovom slučaju, moglo dodati i to da je pojam ekološke svesti u tesnoj vezi sa krizama koje se pojavljuju u nekoj zemlji, ili, kao što je upravo slučaj sa pandemijom, u čitavom svetu. Istraživanje prirode, obilasci znamenitih prirodnih i kulturno-istorijskih spomenika,u tom slučaju postaju masovna tendencija. Ekoturizam, kao vodeća grana turizma, postaje bitan oblik kretanja ljudi. Jedna od definicija ove oblasti turizma ukazuje na očuvanje životne sredine $i$ ističe bitnu ulogu ekoturizma: „Ekoturizam je deo turizma koji je odgovoran za redukovanje štetnih uticaja na životnu sredinu, i kao takav značajno podstiče rurarni kulturni integritet" (Vujović i dr., 2020). Prema Laziću i Stojanoviću „ekoturizam je sastavni deo održivog razvoja i jedan od najbrže rastućih segmenata turističke privrede, fokusiran na zaštitu prirode, društveni i ekonomski razvoj" (Lazić, Stojanović, 2020). Još jedna sveobuhvatna definicija ekoturizma ističe da je ekoturizam „vid turizma koji se usredsređuje na održanje biološke i kulturne baštine, neutrališe siromaštvo seoskih sredina, povezuje ljude, pojačava ekološku svest, potencira očuvanje ekološke sredine i sve to čini kroz prizme: ekonomije - dobijanje prihoda od turista; socijalne - jačanje međuljudskih odnosa; zdravstvene - zaštite čoveka i životne sredine" (Štetić, Trišić, 2020). Neki autori smatraju da je ekoturizam „svrsishodno putovanje sa ciljem da se upozna kultura, kao i flora i fauna određenog područja, pri čemu se vodi računa da ekosistem tog područja ostane netaknut, istovremeno se pruža prilika za ostvarivanje prihoda koji lokalnom stanovništvu koristi za očuvanje prirodnih resursa" (Božić, 2019). Iz pomenutih definicija mogu se izvesti četiri funkcionalno zavisne komponente, koje čine ekoturizam, a odnose se na:

- $\quad$ prirodu - prirodno okruženje netaknutih bogatstava flore i faune kao i prirodno nastalih istorijskih specifičnosti. „Izgrađivanje ekološke i kulturne svesti i poštovanja" (Mladenović, Bojičić, 2020).

- održivi razvoj - razvoj društva koji raspoloživim resursima zadovoljava ljudske potrebe, ne ugrožavajući prirodne sisteme i životnu sredinu. Na taj način se osigurava dugoročno postojanje ljudskog društva i njegovog prirodnog okruženja; „Smatra se da će razvoj turizma na selu doprinositi stvaranju jednakosti i ekonomske i socijalne pomoći lokaloj zajednici, pa i širem okruženju" (Živković i dr., 2020).

- obrazovanje - sticanje bitnih znanja o istorijskim i kulturnim spomenicima, kao i prirodnim bogatstvima koja okružuju ljudsku populaciju;

- ekonomski razvoj - materijalno oplemenjivanje malih rurarnih naselja, uz interakciju prirodnih proizvoda sa novčanim sredstvima.

Kako se $u$ vreme pandemije KOVID-19 ispostavilo da manje razvijene zemlje, koje su ozbiljno pogođene zdravstvenom krizom,a koje su se u najvećoj meri oslanjale na međunarodni turizam, doživljavele ozbiljan nagli pad turističke industrije, ali su usled prekograničnih ograničenja turisti usmereni ka lokalnim objektima, jasno je da će se razviti nacionalni turizam (Varzaru et al., 2021). Zazo se u ovom radu fokus stavlja na razvoj ekoturizma u Srbiji u vreme pandemije KOVID-19, kroz sagledavanje studije slučaja vojvođanske destinacije - Palićko jezero, koje pruža izvanredne uslove za razvoj pomenute grane turizma. 


\section{MATERIJALI I METODE /} MATERIALS AND METHODS

Prostor istraživanja. Palićko jezero, kao atraktivna vojvođanska destinacija, nalazi se u severnom delu Vojvođanske regije, na $7 \mathrm{~km}$ udaljenosti od grada Subotice. Zauzima površinu od oko 712 ha i čini zaštićenu zonu, to jest, kulturno-zaštićenu baštinu Palića. Zbog svoje lekovitosti dubinskog mulja, indukovalo je stvaranje kupališta, kao i pojavu širokog turističkog kompleksa objekata koji obuhvataju prostranu obalu Palićkog jezera. U njegovoj neposrednoj blizini, nalazi se veliki park koji, takođe, predstavlja turističku atrakciju sa bogatim svetom flore i faune. Palićko jezero se odlikuje biljnim vrstama poput: resine, trske, barske perunike i zelene alge koja i daje zelenu boju jezeru. Zbog očuvanog vlažnog staništa, pomenuto jezero omogućava opstanak brojnim zaštićenim životinjskim vrstama: vodozemcima, gmizavcima i sisarima. U okolini jezera, na kopnu, mogu se susresti: bela vrba, hrast lužnjak kao i razne vrste faune sa glavnim predstavnicima, crnoglavim galebom i slepim mišem. Samo jezero zahvata površinu od 500 ha sa dubinom do $3 \mathrm{~m}$, što govori da ovo jezero pripada onim jezerima koja su plića. Sa tim u vezi, područje Palićkog jezera biće posmatrano iz ugla ekoturizma sa glavnom hipotezom ispitivanja broja njegove turističke posećenosti u periodu 2019. i 2020. godine. Rad će pokušati da utvrdi nivo sta- gnacije, rasta ili opadanja turističkih poseta pre i usled pojave COVID-19, kao i mogućnost uklanjanja nabrojanih nedostataka ekoturističke ponude.

\section{REZULTATI I DISKUSIJA / RESULTS AND DISCUSSION}

\subsection{Turistički promet domaćih i stranih turista na Paliću I \\ Tourist traffic of domestic and foreign tourists in Palić}

Pre pandemije virusa KOVID-19, a tokom 2019. godine zabeležen je nagli porast turista na Palićkom jezeru (www.park-palic.rs, www.tvsubotica.com, www.stat.gov.rs). Tada je urađeno istraživanje, koje je doprinelo formiranju mišljenja o tome šta je motivisalo turiste da se opredele za Palićko jezero, kao ekoturističku destinaciju.Ovo istraživanje se pokazalo značajnim jer je istaklo bitne odlike ekoturizma neposredno pre pojave pandemije KOVID-19. Dve stavke koje su dominirale kod ispitanika, koji su posetili Palić, bile su: atraktivne pešačke ture pored jezera i Palićkim parkom (koju je navelo je 50\% ispitanika), i prirodno-istorijski spomenici, manifestacije i bogata domaća kuhinja ovog područja (navelo je $40 \%$ ispitanih turista), dok je stav da im je najbitnije posmatranje retkih vrsta biljaka i ptica, kao i pecanje, navelo tek $10 \%$ ispitanika. (Plan upravljanja spomenika prirode „Stabla hrasta lužnjaka na Paliću“, 2019).

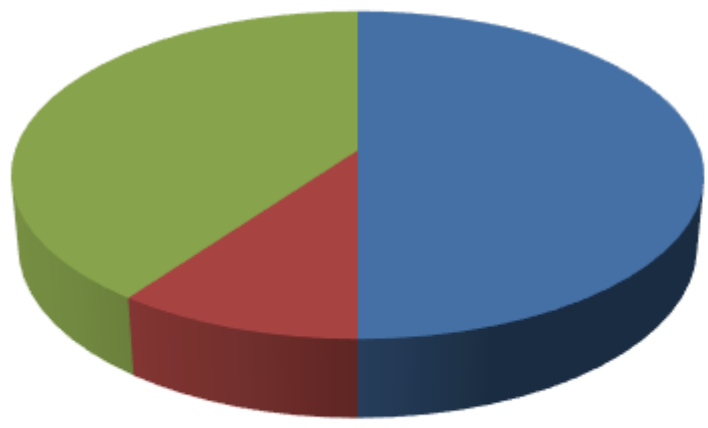

\section{pešačke ture pored jezera i Palićkog parka}
posmatranje retkih biljaka i životinja, pecanje

\section{kulturno-istorijski spomenici,}

Grafikon 1. Šta privlači turiste Palićkom jezeru? Graph 1. What attracts tourists to Lake Palić?

U toku 2019. godine, Republički Zavod za statistiku, evidentirao je povećan broj turista u odnosu na broj turista u 2018. godini. Samo se broj noćenja turista povećao za 23\% u odnosu na ostvaren u 2018. godini. Palićko jezero posetilo je 20779 domaćih i 12889 stranih turista. Od toga Palić beleži cifru od ukupno 62718 noćenja, od čega 42307 čine noćenja domaćih turista, a 20411 stranih turista (Republički
Zavod za statistiku, 2019). Ovi podaci ukazuju na plod ozbiljnog i dugoročnog planiranja razvoja turizma na Paliću od strane DOO Park Palić, koji je upravljačko telo turističkog prostora Palić. Međutim, tokom 2020. godine, došlo je do naglog pada broja turističkih posetilaca na nivou cele Srbije. U Srbiji je boravilo za 53\% manje turista u odnosu na 2019.godinu (Radivojević, 2020). Negativan uticaj COVID-19 na turizam je prikazan i na sajtu Republičkog statističkog 
Zavoda, baš za oblast Palićkog jezera, turističke destinacije koje je i cilj istraživanja u ovom radu. Prema statističkim podacima, posmatranim za period 2020. godine, i to $u$ prvih sedam meseci, broj dolazaka turista na Palić se smanjio za $34,44 \%$, a broj noćenja za $17 \%$ u odnosu na 2019. godinu. Palić, u ovom periodu, beleži dolazak 9932 domaćih turista i 1634 stranih turista. Što se tiče noćenja, na Paliću je boravilo 24377 domaćih turista i 2561 stranih turista (Republički Zavod za statistiku Srbije, 2020). Poređenje noćenja i dolazaka stranih i domaćih turista na Palić za period 2019. i 2020. godina, biće dato kroz grafički prikaz radi lakšeg uočavanja i poređenja dobijenih podataka.

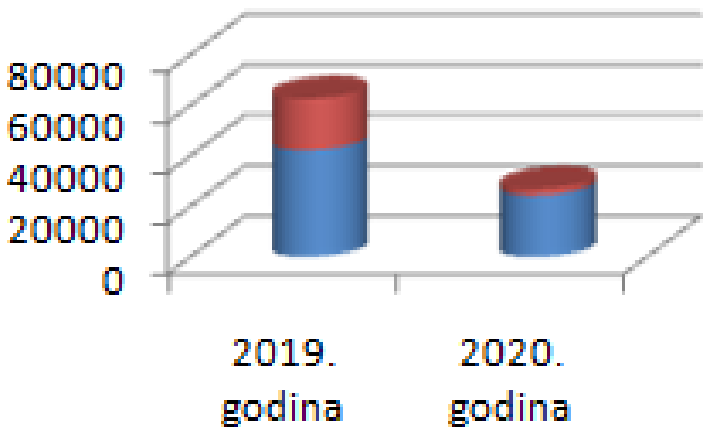

broj dolazaka stranih turista

broj dolazaka domaćih turista

Grafikon 2. Broj dolazaka stranih i domaćih turista na Palićko jezero (Izvor: RSZ, 2019)

Graph 2. Number of arrivals of foreign and domestic tourists on Lake Palić (Source: RSZ, 2019)

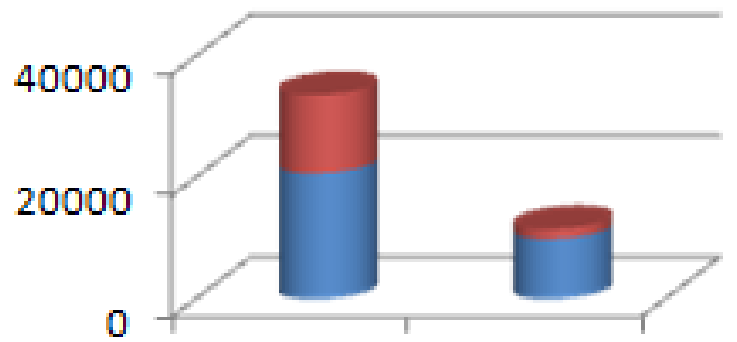

2019.godine 2020.godine
- brojstranih turista na noćenju

broj domaćih turista na noćenju

Grafikon 3. Broj stranih i domaćih turista na noćenju, na Paliću (Izvor: RSZ, 2019)

Graph 3. Number of foreign and domestic tourists per night, in Palić (Source: RSZ, 2019)

Iz prikazanih grafika jasno se uočava opadanje broja turista tokom 2020. godine, u odnosu na 2019. godinu, što je izazvano pojavom KOVID-19 virusa koji je imao negativne uticaje na sve privredne grane, između ostalog, i na turizam. Međutim, otvorenost Palića ka ekoturizmu omogućila je da, na nivou Srbije, ova destinacija pokazuje porast domaćih turista u odnosu na druge destinacije koje nisu pomenutog tipa, za $10 \%$ (RTV, 2021).

\subsection{Modeli razvoja ekoturizma na Palićkom jezeru / Models of ecoturism development on Lake Palić}

Ukoliko uzmemo u obzir zahteve turista koji su izneti i u 2019. godini, jer je to bila godina sa najviše zabeleženih posetilaca na Paliću, ali i teorijska znanja o razvoju ekoturizma, jasno je da se deo ekoturizma koji je povezan sa Palićkim jezerom mora pojačati dodatnim aktivnostima, jer je kod turista došlo do promene u motivaciji ka odabiru destinacije ekoturizma. $U$ turističkom sektoru efekti prirodnih katastrofa dovode do aktuelnih pitanja održivosti (Williams, Horodnic, 2021), koja se mora odnositi na obnavljanje i konsolidaciju turističke industrije, pružanjem čistijeg prirodnog okruženja koje nudi više turističkih mogućnosti i koristi ljudski kapital (Varzaru et al., 2021). Akcenat razvoja ekoturizma u toku i nakon pandemije KOVID19, koja traje već godinu ipo dana, mora se bazirati na upražnjavanju različitih aktivnosti uz pomoć kojih turisti stiču veštine i posebna interesovanja: vožnja čamcem ili brodićem, vožnja fijakerom, vazdušnim balonom ili paraglajderom, jahanje konja, istraživačke ekspedicije, etno-radionice. 
Jedno od istraživanja čiji je bitan segment bilo ispitivanje važnosti motiva za ishod odabrane destinacije ekoturizma, donosi sledeće rezultate:

\section{Tabela 1. Važnost motiva za ishod odabira destinacije ekoturizma}

Table 1. Importance of motives for the outcome of choosing an ecotourism destination

\begin{tabular}{|c|c|}
\hline $\begin{array}{c}\text { Važnost (od } \\
\text { najvažnijeg do } \\
\text { najmanje važnog) }\end{array}$ & Motiv \\
\hline 1 & Priroda \\
\hline 2 & Zdravlje \\
\hline 3 & Avantura \\
\hline 4 & Kultura \\
\hline 5 & Cena \\
\hline 6 & Kulturna baština \\
\hline 7 & Sport i rekreacija \\
\hline 8 & Gastronomija \\
\hline 9 & Umetnosti i zanati \\
\hline
\end{tabular}

Izvor / Source: Božović et al., 2021

Iz tabele se jasno uočava da je motivisanost turista ka ekoturozmu usmerena, na prvom mestu, ka prirodi, zdravlju i željom za avanturom, a to i jesu vrednosti koje su dobile na značaju u vreme pandemije KOVID-19. Ljudi se okreću ka zdravijem životu, ka odmoru koji je daleko od urbanih, prenaseljenih sredina koje su postale žarište virusa, i ka avanturama u prirodi koje ne ugrožavaju njihovo zdravlje, ali i čine suprotnost danima provdenim u karantinu i zatvorenim prostorima. Briga i strah za očuvanje sopstvenog zdravlja postaju prioriteti pri izboru ekoturističke destinacije. Nešto što je, takođe, visoko kotirano u motivima koji utiču na okrenutost turista ka ekoturizmu jesu kultura, odnosno upoznavanje i negovanje kulturnih vrednosti, zatim cena koja mora biti prihvatljiva i koja nije previsoka.

Kako je Palićko jezero osetljiv ekosistem, on teško može da izdrži sve sadržaje koji su neophodni jednoj turističkoj atrakciji. lako se razvija kao velnes, kupališni i sportsko-rekreativni centar, on ima vrlo malo ekoturističkih programa i odlikuje se ekološkom izdrživošću koja je diskutabilna upravo zbog zagađenosti samog jezera. Otuda bi ubrzavanje rada na pročišćavanju jezera bio prioritet. U okviru toga, velika pažnja bi se morala posvetiti uvođenjem ekoloških taksi, zatim negovanju kulture gajenja ekoloških namirnica u ishrani koja se nudi turistima, osmišljavanje različitih sadržaja koji će zadovoljiti potrebe turista za avanturom, ali i negovanjem i upoznavanjem kulturne baštine svih nacionalnih manjina koje žive na prostoru Palića: Mađari, Rusini, Slovaci, Hrvati. Takođe, neophodna je ograničena izgradnja objekata za smeštaj koji se moraju estetski uklopiti u ambijent toga dela Vojvodine, zatim veća promocija kulturne raznolikosti kroz podsticanje lokalnog stanovništva da ponudi svoje proizvode kroz različite manifestacije, ali je neophodan i planski rad na strategiji podsticanja svih oblika ekoturizma koji se baziraju na resursima flore i faune Palićkog jezra. Nikako ne treba izostaviti aktivnu uključenost lokalne zajednice koja treba da pruži podršku svim preduzetnicima koji žele da na teritoriji Palićkog jezera pokrenu sopstveni biznis vezan za ekoturizam. Takođe, veoma je važno intenzivirati marketing kojim će se privući veći broj domaćih i stranih turista, jer je utvrđeno da turisti najviše informacija dobijaju sa Interneta, od prijatelja i rodbine, i iz brošura (Ramchurjee, 2020).

\section{ZAKLJUČAK / CONCLUSION}

Pad rasta privredne grane turizma, izazvan virusom KOVID-19, može se zaustaviti ekoturizmom Palića, na taj način što će se domaći i strani turisti primamiti gostovanjem u manjim aktiviranim vilama, koje su bezbednije po širenje virusa KOVID-19, a pružiće im se atraktivne šetnje i duži boravak u otvorenim prirodnim okruženjima. $\mathrm{Na}$ taj način se ekoturizam može ponovo uspešno aktivirati i povećati broj turističkih posetilaca, sobzirom na to da je evidentno da su se motivi kod turista koji biraju ekoturizam pomerili od toga da su, pre epidemije Kovida-19, bili visoko motivisani za posete kulturnoistorijske spomenike, dok se u toku pandemije pojavljuje kao ključni motiv - zdravlje. Tako se pojačao značaj zdravstvenog aspekta ekoturizma, jer su ljudi počeli da pribegavaju dužim i kvalitetnijim boravcima u prirodi zato što su unapredili svoju ekološku svest, ali i stoga što žele da se zaštite od virusa i ojačaju svoj imuitet. Takođe, pojačalo se njihovo interesovanje za proučavanjem flore i faune, a takođe i predela koji su autentični i zaštićeni, u šta možemo ubrojiti i Palićko jezero.

U budućnosti će se ostvariti Akcioni planovi grada Palića koji se odnose na prečišćavanje vode u Palićkom jezeru, što će popraviti biodiverzitet pomenutog jezera i očuvati raritetne oblike flore i faune. Na nacionalnom nivou, razvoju ekoturizma doprinose i vaučeri koje Ministarstvo turizma nudi zainteresovanim građanima i pomaže im, da uz pomoć te olakšice, povoljnije ostvare svoj odmor.

Palićko jezero ima dobre izglede za razvoj ekoturizma u vreme pandemije KOVID-19 jer može da ponudi turistima zanimljivu ponudu, koja im uliva poverenje da se u prirodi i zdravom okruženju mogu u većoj meri zaštiti od epidemije, nego što će im to biti moguće u urbanim sredinama. 


\section{LITERATURA / REFERENCES}

[1] Božić, N., (2019), Ekoturizam, Beograd: Univerzitet Singidunum, str. 10.

[2] Božović, S., Košić, K., Vukoičić, D., (2021), Razvoj ekoturizma u uslovima pandemije: slučaj planine Zlatibor u Srbiji, Ecologica 28(102), 215-222.

[3] Bulatović, D., Pećić, M., Ostojić, B., (2019), Kontradiktornost između ekološke svijesti i djelovanja i potreba suzbijanje ekološkog kriminala, Ecologica, 26(96), 545-551.

[4] Janković, M., Ivannikov, N., Jovanović, L., Gajdobranski, A., (2020), Doprinos zelene ekonomije razvoju ekoturizma i organskoj proizvodnji, Ecologica, 27(98), 217-223.

[5] Lazić, L., Stojanović, V., (2020), Strategija razvoja ekoturizma regiona - SRP Slano kopovo i Nadašto zolovni park, Interreg - IPA CBC, Novi Bečej, str. 1.

[6] Mladenović, M., Bojičić, R., (2020), Razvoj ekoturizma u opštini Štrpce - mogućnosti i perspektive, Ecologica, 27(98), 232-239.

[7] Plan upravljanja spomenika prirode „Stabla hrasta lužnika na Paliću“ (2015). JP „Palić-Ludoš“, Subotica, str. 23.

[8] Ramchurjee, N., (2020), Understanding the relationship between tourists motivacions and their experience and satisfaction, International Journal of Development and Sustainability, 2(3), 17581769.

[9] Radivojević, A., (2020), Turistički sektor u Republici Srbiji tokom trajanja pandemije. Beograd: Fondacija za razvoj ekonomske nauke, Ekonomski fakultet, str. 43.

[10] Republički Zavod za statistiku, (2019), https://www.stat.gov.rs/sr- latn/oblasti/ugostiteljstvo-i-turizam/turizam/, Pristupljeno: 20. 3. 2021.

[11] Republički Zavod za statistiku, (2020), https://www.stat.gov.rs/sr-

Latn/oblasti/ugostiteljstvo-i-turizam/turizam, Pristupljeno: 17.3.2021.

[12] RTV, https://rtv.rs/sr_lat/vojvodina/backa/napalicu-desetkovan-broj-nocenja-stranih-turistadomacih-turista-sve-vise_1206648.html, Pristupljeno: 20.3.2021.

[13] Štetić, S., Trišić, I., (2020), Prirodni resursi za razvoj ekoturizma Specijalnog rezervata prirode „Obedska bara”, Ecologica, 27(98), 224-231.

[14] Vărzaru, A., Bocean, C., Cazacu, M., (2021), Rethinking Tourism Industry of Pandemic COVID-19 Period, Sustainability, 2021, 13, 6958.

[15] Vujović, S., Premović, J., Arsić, Lj., (2020), Ekološki aspekti materijalne osnove ruralnog turizma, Ecologica, 27(97), 65-69.

[16] Živadinović, B., (2020), Eko-restorani u svetu i restorani u Srbiji, Ecologica, 27(97), 70-74.

[17] Živković, D., Petrović, P., Ercegović, M., (2020), Način finansiranja malih i srednjih preduzeća u hotelijerstvu i eko-turizam, Ecologica, 27(97), 7581.

[18] Williams, C., Horodnic, A., (2020), Tackling Undeclared Work in the Tourism Sector. European Plaform Tackling Undeclared Work, https://ec.europa.eu/social/BlobServlet?docld=2 2868\&langld=en, Pristupljeno: 20.9.2021.

[19] www.park-palic.rs Pristupljeno: 20. 9. 2021.

[20] www.tvsubotica.com Pristupljeno: 20. 9. 2021.

[21] www.stat.gov.rs Pristupljeno: 20. 9. 2021. 